\title{
Biological confirmation of resistance from segregating populations of Gherkin (Cucumis anguria L.) against cucumber mosaic virus (CMV)
}

\section{H. L. Venkatesh}

Department of plant pathology, Department of Genetics and Plant Breeding, University of Agricultural Sciences, GKVK, Bengaluru-560065 (Karnataka), India

\section{V. Kavyashri*}

Department of plant pathology, Department of Genetics and Plant Breeding, University of Agricultural Sciences, GKVK, Bengaluru-560065 (Karnataka), India

\section{A. S. Padmaja}

Department of plant pathology, Department of Genetics and Plant Breeding, University of Agricultural Sciences, GKVK, Bengaluru-560065 (Karnataka), India

\section{N. Nagaraju}

Department of plant pathology, Department of Genetics and Plant Breeding, University of Agricultural Sciences, GKVK, Bengaluru-560065 (Karnataka), India

S. Ramesh

Department of plant pathology, Department of Genetics and Plant Breeding, University of Agricultural Sciences, GKVK, Bengaluru-560065 (Karnataka), India

*Corresponding author. E-mail: kavyashrivv@gmail.com

\begin{abstract}
Cucumber Mosaic Virus (CMV) is most widespread and destructive disease of gherkin (Cucumis anguria L.) Most of the commercial varieties are susceptible to CMV disease. Thus, identification of resistant genotypes for management of CMV disease in gherkin is essential. A total of $179 \mathrm{~F} 3$ progenies derived from crosses of resistant and susceptible parent's viz., Acc.1 (susceptible) x Acc. 50 (resistant), Acc.3 (susceptible) x Acc.50 (resistant), Acc.48 (susceptible) x Acc 50 (resistant) were screened for CMV. Among 179 F3 families, 7 were Immune, 17 were Resistant, 76 were Moderately Resistant, 73 were Moderately Susceptible and 6 were Susceptible. The immune and resistant progenies were further confirmed for their resistance reaction by aphid transmission. Significant difference between the estimates of PDI or F3 progenies mapped into different response classes justified the classification.
\end{abstract}

Keywords: CMV, F3 Progenies, Gherkin, Resistant, Screening, Susceptible

\section{Article Info}

DOI: 10.31018/jans.v11i1.1979 Received: December 27, 2018 Revised: February 26, 2019 Accepted: February 28, 2019

\section{How to Cite}

Venkatesh, H.L. et al. (2019). Biological confirmation of resistance from segregating populations of Gherkin (Cucumis anguria L.) against cucumber mosaic virus (CMV). Journal of Applied and Natural Science, 11(1): 199-204

\section{INTRODUCTION}

Cucurbits, which belong to the family Cucurbitaceae are important vegetable crops which include melons, squash, cucumber, gourds, pumpkin and gherkin. Cucurbits are good sources of carbohydrates, vitamin $A$ and $C$ and minerals (Nath, 1979). Among cucurbits, gherkin (Cucumis anguria L.) also known as pickling cucumber was introduced to India in 1990. It is one of the important export oriented crops commonly known as West Indian burr gherkin. Among gherkin growers, it is commonly known as small cucumber. In India, gherkin is a 100 per cent export oriented crop as there is very little scope for domestic consumption. The export of gherkins is valued upto Rs.502 crores annually. Bottled gherkins pickled in vinegar contribute nearly 50 per cent of the exports (Sukumaran, 2007). Since, gherkin is a high value export oriented crop and area planted to gherkin is increasing rapidly. Consequently, gherkin is being grown on a variety of soils under varied agroclimatic situations. As a result, the crop has become susceptible to many biotic and abiotic stress. Gherkin is susceptible to a variety of fungal and viral diseases (Mugadur and Nittur, 2011). Of these, diseases caused by viruses constitute the major biotic constraints in gherkin production. The important viral diseases includes those caused by Cucumber Mosaic Virus (CMV), Zucchini Yellow Mosaic Virus (ZYMV), Papaya Ring Spot Virus (PRSV), Watermelon Mosaic Virus (WMV), Potato Virus Y (PVY), Tobacco Mosaic Virus (TMV), Tobacco streak virus (TSV) and Tomato Spotted Wilt Virus (Tospo virus) (Gracia, 2000; Krishna Reddy et al., 2003; Viraktamath et al., 2003; Mugadur and Nittur, 2011).

Among virus diseases, Cucumber mosaic virus $(\mathrm{CMV})$ is most destructive causing yield losses as 
high as 40-60 per cent (Varma and Giri, 1998). CMV, a positive-sense ssRNA plant virus with a tripartite genome, is the type member of the genus Cucumovirus in the family Bromoviridae (Ribicki, 1995). The CMV is transmitted by Aphis gossypii Glover and Myzus persicae in a nonpersistent manner (Chandankar et al., 2013; Coudriet, 1962). Most of the commercial varieties of Gherkins are susceptible to CMV and the currently available chemical/cultural methods are either ineffective or uneconomical. Thus, identification of resistant genotypes for management of CMV disease in gherkin (Cucumis anguria L.) is essential. The present study was to identify and select progenies resistance to CMV from F3 segregating populations.

\section{MATERIALS AND METHODS}

Plant material: The gherkin material (Cucumis anguria L.) consisted of 179 F3 progenies derived from crosses of resistant and susceptible parent's viz., Acc.1 (susceptible) x Acc. 50 (resistant), Acc. 3 (susceptible) x Acc.50 (resistant), Acc.48 (susceptible) $\times$ Acc 50 (resistant). The crosses Acc. 1 x Acc. 50, Acc. 3 x Acc. 50 and Acc. 48 x Acc. 50 will be hereafter referred to as A 1-50, A 3 -50 and A 48-50, respectively.

Preparation of inoculum: Young leaves of susceptible check showing typical symptoms of CMV were grounded in a pestle and mortar with $0.1 \mathrm{M}$ phosphate buffer ( $\mathrm{pH} 7.0)$ containing $0.2 \%$ sodium sulfite in the ratio of 1:5 (g:ml) leaf and buffer. The sap was then filtered through a double layered muslin cloth and collected in a beaker. About $1.0 \%$ of celite 545 was added to the sap as an abrasive. This inoculum was applied with a cotton swab on the young leaves of 10-15 days old test plants. After inoculation, the inoculated plants were lightly misted with distilled water and maintained in the insect proof greenhouse for symptom expression. Then per cent disease index was calculated.

Screening F3 progenies for response to CMV disease: Thirty seeds of 179 F3 progenies were sown in ten polythene covers of $4^{\prime} \times 6^{\prime}$ with three seeds per polythene cover filled with a mixture of soil, manure and coir pith. An equal number of seeds of susceptible check were sown in similar manner as a positive control. The 12 to 15 days old seedlings of F3 progenies along with susceptible check were inoculated with CMV by sap inoculation method as described by Mandal et al. (2001) under glass house condition at Main Research Station (MRS), Hebbal, Bengaluru.

Disease scoring and estimation of Per cent Disease Index (PDI): The seedlings of F3 progenies were scored using 0-5 scale (Bos, 1982) for the disease based on the symptom typical to the disease at 10-days interval for a period of 30 days after inoculation (DAI).

Scale used to score symptoms typical to CMV

\author{
disease \\ Scale Description of symptoms \\ 0 : No symptoms \\ 1 : Very light mottling of older leaves and \\ dark green colour in younger leaves \\ 2 : Light and dark green areas associated \\ with veins \\ 3 : Mosaic, blistering and puckering of leaves \\ $4:$ Distortion of leaves \\ 5 : Stunting of the plants with negligible or no \\ flowering
}

Per cent disease index (PDI) was calculated by using the following formula (Silbernagel and Jafari, 1974).

$\mathrm{PDI}=0 \mathrm{n}_{0}+1 \mathrm{n}_{1}+2 \mathrm{n}_{2}+3 \mathrm{n}_{3}+4 \mathrm{n}_{4}+5 \mathrm{n}_{5} / \mathrm{nt}(\mathrm{nC}-1) \mathrm{X}$ $100 \quad \ldots \ldots \ldots$.Eq. 1

Where, $\mathrm{n}_{0}, \mathrm{n}_{1}, \mathrm{n}_{2}, . ., \mathrm{n}_{5}=$ No. of plants in score 0 , $1,2, \ldots, 5$, respectively, nt $=$ total no. of plants, and $\mathrm{nC}=$ Total number of categories.

Classification of F3 progenies into different response groups based on estimates to PDI (Havey, 1996):

$\begin{array}{ll}\text { Estimate of PDI } & \text { Disease reaction } \\ 0 & : \text { Immune (I) } \\ 1-25 & \text { : Resistant (R) } \\ 26-50 & \text { : Moderately resistant (MR) } \\ 51-75 & \text { : Moderately susceptible (MS) } \\ 76-100 & \text { : Susceptible (MS) }\end{array}$

The significance of difference in mean PDI of F3 progenies classified into different groups was pre-examined using $\mathrm{F}$ test.

Screening of selected F3 progenies by Aphid Transmission

Maintenance of aphid culture: Aphid species Aphis gossypii Glover was multiplied on cotton plants. The cotton plants were kept inside small insect proof wooden cages, previously sprayed with Dimethoate 0.2 per cent to ensure insect free condition of cages (Plate 1).

Pre-acquisition period (Starvation): Aphids were allowed to starve for $2 \mathrm{hr}$. in a petri dish, placed in a dark chamber before releasing on to the symptomatic leaves of infected cotton plants for acquisition feeding.

Acquisition access period (AAP): The prestarved aphids were allowed to feed on infected gherkin leaves showing characteristic mosaic symptoms and were kept turgid by putting a cotton swab at the detached end of the leaf petiole. The aphids were allowed for acquisition feeding time of $10 \mathrm{~min}$. After acquisition feeding period the viruliferous aphids were released on to gherkin seedlings of selected F3 progenies at the rate of 10 aphids per genotype. After $10 \mathrm{~min}$. of IAP, aphids were killed by spraying 0.05 per cent Imidacloprid. The inoculated plants were kept in insect proof cages for symptom development.

\section{RESULTS AND DISCUSSION}

Response of F3 progenies for CMV disease infection: The present study showed that PDI of Gherkin (Cucumis anguria L.) 179 F3 progenies ranged from $0 \%$ to $86.67 \%$. Based on mean PDI 
Venkatesh, H.L. et al. / J. Appl. \& Nat. Sci. 11(1): 199-204 (2019)

Table 1. Grouping of gherkin F3 progenies based on disease reaction to Cucumber mosaic virus.

\begin{tabular}{|c|c|c|c|c|}
\hline \multirow[t]{2}{*}{ PDI (\%) } & \multirow{2}{*}{$\begin{array}{l}\text { Disease } \\
\text { reaction }\end{array}$} & \multicolumn{3}{|c|}{ Families derived from crosses } \\
\hline & & Acc. $1 \times$ Acc. 50 & Acc. $3 \times$ Acc. 50 & Acc. $48 \times$ Acc. 50 \\
\hline 0 & Immune (07) & 17,35 and 62 & 26 and 34 & 11 and 47 \\
\hline $1-25$ & Resistant (17) & 65 & $\begin{array}{l}5,8,16,18,22,38 \\
\text { and } 43\end{array}$ & $\begin{array}{l}24,31,40,43,48,60 \\
61,66 \text { and } 67\end{array}$ \\
\hline $26-50$ & $\begin{array}{l}\text { Moderately re- } \\
\text { sistant (76) }\end{array}$ & $\begin{array}{l}2,6,7,8,11,13,26,27,42 \\
44,50,51,54,55,56,57 \\
58,60,64,66 \text { and } 67\end{array}$ & $\begin{array}{l}4,8,9,10,13,14,15 \\
17,21,23,24,25,27 \\
28,29,31,32,37,37 \\
39,39,40,42,44,45 \\
46,50 \text { and } 52\end{array}$ & $\begin{array}{l}2,5,12,14,16,17, \\
18,22,25,27,34,36, \\
38,39,41,42,44,46, \\
50,51,52,55,56,58, \\
63,64,72\end{array}$ \\
\hline $51-75$ & $\begin{array}{l}\text { Moderately sus- } \\
\text { ceptible (73) }\end{array}$ & $\begin{array}{l}1,3,4,5,10,14,15,19,21 \\
22,23,24,25,28,29,30 \\
31,32,33,34,36,37,38 \\
39,40,41,43,45,46,49 \\
52,53,60 \text { and } 63\end{array}$ & $\begin{array}{l}1,2,6,11,12,20,33 \\
35,41,47,48 \text { and } 51\end{array}$ & $\begin{array}{l}1,5,6,8,9,10,13, \\
15,19,20,23,26,29, \\
30,32,33,35,37,49, \\
53,54,62,65,68,69, \\
70 \text { and } 74\end{array}$ \\
\hline $76-100$ & Susceptible (06) & 20 & 3,19 and 30 & 4 and 57 \\
\hline
\end{tabular}

Table 2. Mean PDI of $F_{3}$ families classified into different response groups.

\begin{tabular}{|c|c|c|c|c|c|c|}
\hline \multirow{2}{*}{$\begin{array}{l}\text { Disease reaction cate- } \\
\text { gories }\end{array}$} & \multicolumn{2}{|c|}{ Acc. 1-50 } & \multicolumn{2}{|c|}{ Acc. 3-50 } & \multicolumn{2}{|c|}{ Acc. $48-50$} \\
\hline & $\begin{array}{l}\text { Number of } \\
\text { F3 families }\end{array}$ & $\begin{array}{l}\text { Mean } \\
\text { PDI }\end{array}$ & $\begin{array}{l}\text { Number of } \\
\text { F3 families }\end{array}$ & $\begin{array}{l}\text { Mean } \\
\text { PDI }\end{array}$ & $\begin{array}{l}\text { Number of } \\
\text { F3 families }\end{array}$ & Mean PDI \\
\hline Immune & 03 & 00.00 & 02 & 00.00 & 02 & 00.00 \\
\hline Resistant & 01 & 14.67 & 07 & 13.38 & 09 & 19.27 \\
\hline Moderately resistant & 21 & 40.18 & 28 & 39.68 & 27 & 39.97 \\
\hline Moderately susceptible & 34 & 62.04 & 12 & 62.28 & 27 & 58.93 \\
\hline Susceptible & 01 & 84.00 & 03 & 83.33 & 02 & 85.00 \\
\hline F value & 98.50 & & 94.61 & & 134.26 & \\
\hline$P$ value & $2.11 \mathrm{E}-24$ & & 7.19E-22 & & 8.36E-30 & \\
\hline
\end{tabular}

PDI- Per cent disease incidence

Table 3. F3 progenies with immune and resistant response to CMV disease infection under challenged disease pressure.

\begin{tabular}{|c|c|c|c|c|c|}
\hline \multirow{2}{*}{$\begin{array}{l}\text { Category of Disease re- } \\
\text { action }\end{array}$} & \multirow[t]{2}{*}{ Families } & \multicolumn{3}{|c|}{ Per cent Disease Index (PDI) } & \multirow[t]{2}{*}{ Mean PDI } \\
\hline & & $10 \mathrm{DAl}$ & 20 DAl & 30 DAI & \\
\hline \multirow{7}{*}{$\begin{array}{l}\text { Immune (Seven fami- } \\
\text { lies ) }\end{array}$} & $1-17$ & 0.00 & 0.00 & 0.00 & 0.00 \\
\hline & $1-35$ & 0.00 & 0.00 & 0.00 & 0.00 \\
\hline & $1-62$ & 0.00 & 0.00 & 0.00 & 0.00 \\
\hline & $2-36$ & 0.00 & 0.00 & 0.00 & 0.00 \\
\hline & $2-34$ & 0.00 & 0.00 & 0.00 & 0.00 \\
\hline & 3-11 & 0.00 & 0.00 & 0.00 & 0.00 \\
\hline & $3-47$ & 0.00 & 0.00 & 0.00 & 0.00 \\
\hline \multirow[t]{17}{*}{ Resistant (17 families) } & $1-65$ & 0.00 & 24.72 & 42.86 & 22.86 \\
\hline & $2-5$ & 0.00 & 14.67 & 19.05 & 11.24 \\
\hline & $2-8$ & 0.00 & 8.56 & $21 . .08$ & 23.93 \\
\hline & $2-16$ & 0.00 & 12.67 & 21.12 & 9.89 \\
\hline & $2-18$ & 0.00 & 14.98 & 23.48 & 12.82 \\
\hline & $2-22$ & 0.00 & 0.00 & 34.28 & 11.43 \\
\hline & $2-38$ & 0.00 & 11.12 & 26.78 & 12.63 \\
\hline & $2-43$ & 0.00 & 10.68 & 26.67 & 11.68 \\
\hline & $3-24$ & 0.00 & 5.61 & 36.00 & 13.87 \\
\hline & 3-31 & 0.00 & 13.36 & 25.72 & 13.03 \\
\hline & $3-40$ & 0.00 & 15.47 & 18.78 & 11.42 \\
\hline & $3-43$ & 0.00 & 12.48 & 26.75 & 13.08 \\
\hline & $3-48$ & 0.00 & 13.69 & 19.27 & 10.96 \\
\hline & $3-60$ & 0.00 & 9.98 & 21.21 & 10.39 \\
\hline & $3-61$ & 0.00 & $14 . .44$ & 23.33 & 12.59 \\
\hline & $3-66$ & 0.00 & 14.67 & 19.56 & 11.41 \\
\hline & $3-67$ & 0.00 & 10.68 & 21.33 & 10.67 \\
\hline
\end{tabular}

$1=F_{3}$ families derived from cross Acc. 1 x Acc. 50; $2=F_{3}$ families derived from cross Acc. $3 \times$ Acc. 50;3= $F_{3}$ families derived from cross Acc. $48 \times$ Acc. 50 
Venkatesh, H.L. et al. / J. Appl. \& Nat. Sci. 11(1): 199-204 (2019)

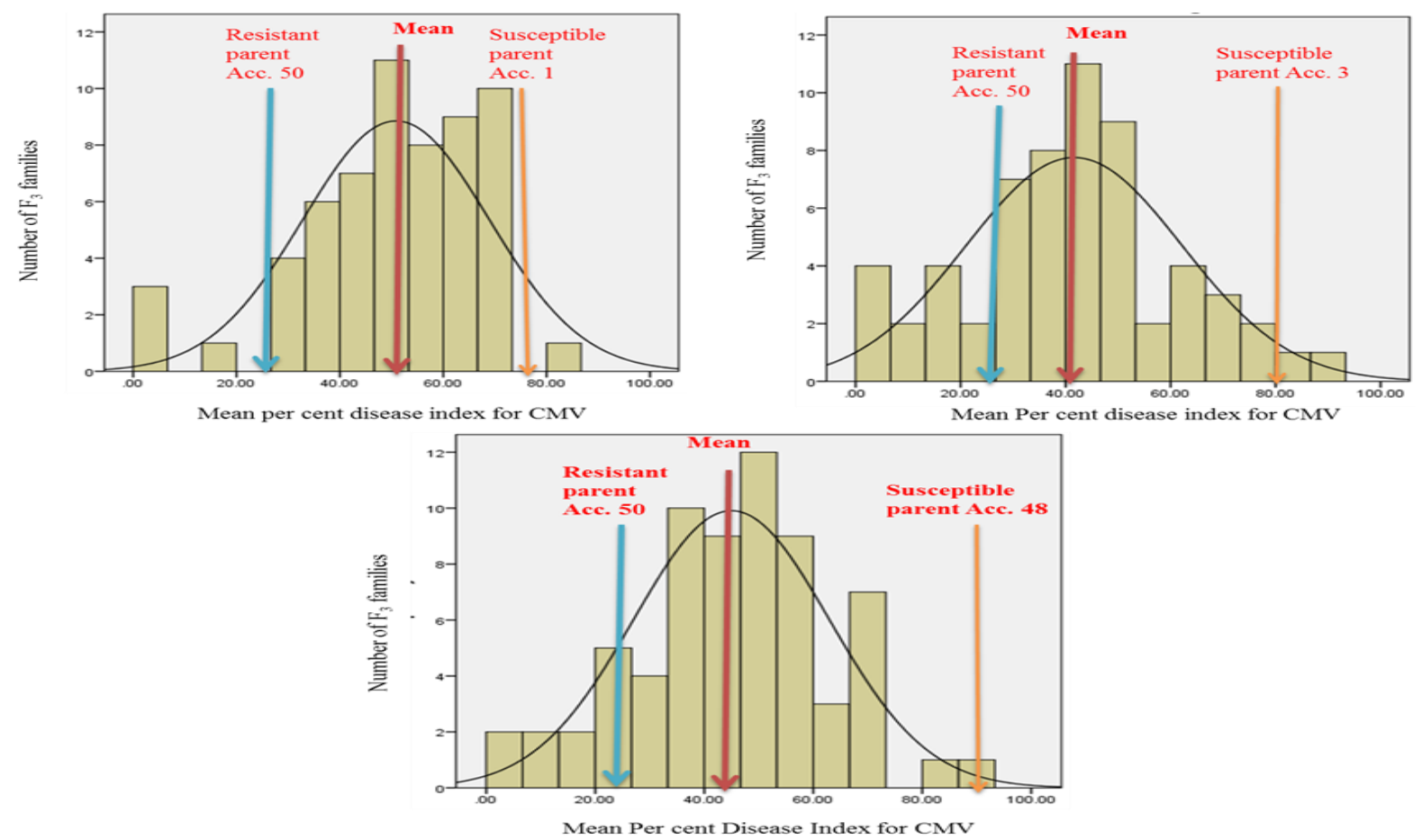

Fig. 1. Distribution of $F_{3}$ families derived from the Acc. $1 \times$ Acc. 50, Acc. 3 × Acc. 50 and Acc. $48 \times A c c .50$ for mean PDI.

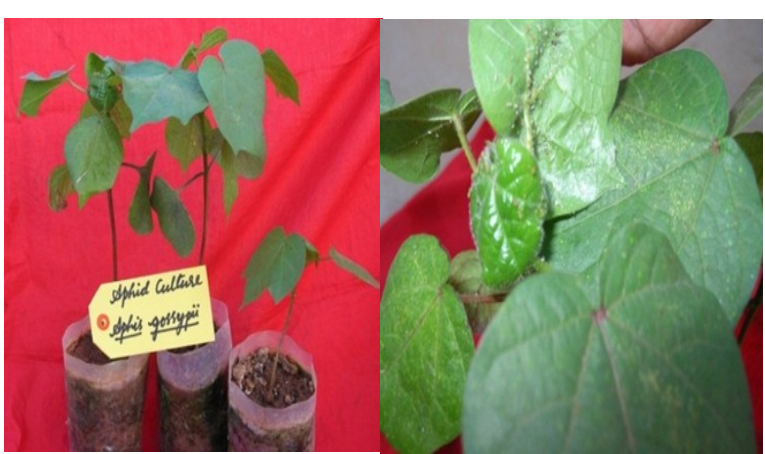

Plate 1. Maintenance of aphid (Aphis gossypii Glover) culture on cotton plants.

values, the accessions were categorized into different categories. The mean PDI in F3 families in each disease reaction category derived from crosses viz., Acc. 1 x Acc. 50, Acc. 3 x Acc. 50 and Acc. $48 \times$ Acc. 50 showed significant difference based on $P$ value. The results showed that $P$ value is less than $F$ value indicating that there is significant difference between the categories viz., immune, resistant, moderately resistant, moderately susceptible and susceptible reaction and disease scoring scale used for the screening of gherkin genotypes is efficient. There is substantial proportion of $\mathrm{F} 3$ families which are better than the resistant parent in all the three crosses viz., Acc.1 $\times$ Acc. 50 , Acc. $3 \times$ Acc. 50 and Acc. $48 \times$ Acc. 50 . The differential reaction of gherkin genotypes to CMV infection might be due to host biochemical's within the genotypes.

The analysis of all the F3 families for mean per cent disease index derived from all three crosses viz., Acc. $1 \times$ Acc. 50, Acc. $3 \times$ Acc. 50 and Acc. $48 \times$ Acc. 50 (Fig. 1) showed there is substantial proportion of $\mathrm{F} 3$ families which are better than resistant parent Acc. 50.

Among 179 F3 progenies, seven of 179 F3 progenies were found Immune $\left(17,35\right.$ and $62 F_{3}$ families derived from cross Acc.1-50, 26 and $34 F_{3}$ family derived from cross Acc.3-50 and 11 and 47 $\mathrm{F}_{3}$ family from Acc.48-50) (Plate 2a, $2 \mathrm{~b}$ and $2 \mathrm{c}$ ). However, 17 F3 progenies showed resistant reaction (R), 76 F3 progenies showed moderately resistant reaction (MR), 73 F3 progenies showed moderately susceptible reaction (MS) and 6 F3 progenies showed susceptible reaction (S) (Table 1). These F3 progenies were confirmed serologically for the presence of virus through DASELISA. All the progenies showed positive reaction to CMV specific antisera except those F3 progenies which showed immune reaction to CMV. The grouping of gherkin F3 progenies on their reaction to the CMV is presented in Table 2. The estimate of mean PDI of F3 progenies classified into different response groups differed significantly suggesting the efficiency of scale and classification. The mean PDI in $F_{3}$ families classified into different response groups differed significantly justifying the classification of F3 progenies.

The immune and resistant F3 progenies identified were further assessed for response to CMV by aphid transmission (Aphis gossypii Glover) with one hour starvation followed by $10 \mathrm{~min}$ AAP and IAP. The similar reaction of accessions to CMV 
Venkatesh, H.L. et al. / J. Appl. \& Nat. Sci. 11(1): 199-204 (2019)

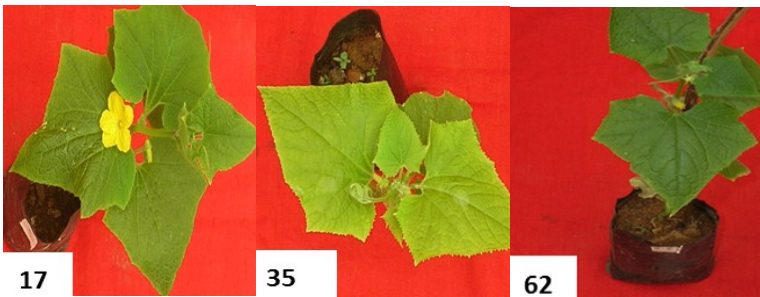

Plate 2a. Gherkin F3 progenies derived from cross Acc. 1 x Acc. 50 showing immune reaction to CMV.

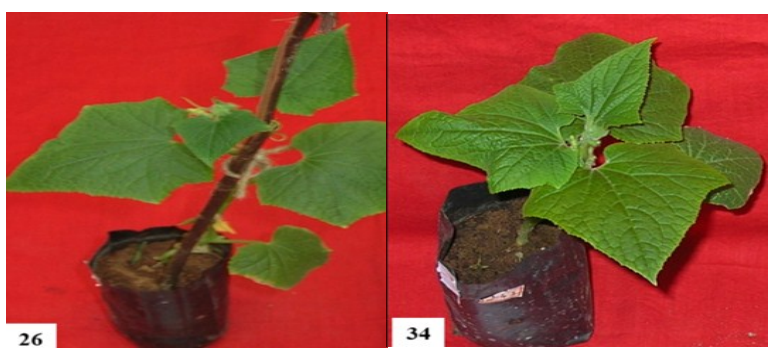

Plate 2b. Gherkin F3 progenies derived from cross Acc. $3 \times$ Acc. 50 showing immune reaction to CMV.

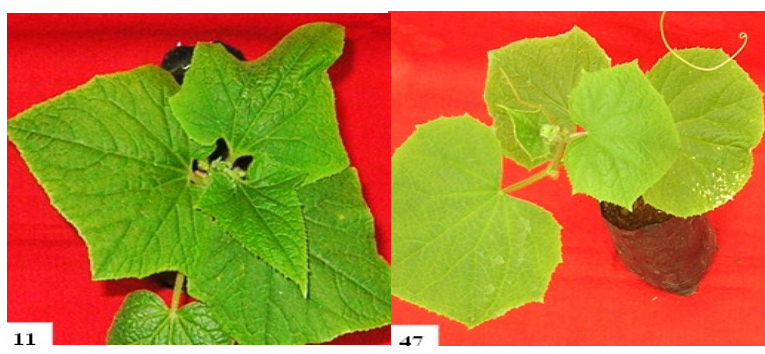

Plate 2c. Gherkin F3 progenies derived from cross Acc. 48x Acc. 50 showing immune reaction to CMV.

was observed as described in sap inoculation. The results of aphid transmission done on selected F3 progenies are presented in the table 3.

The disease reaction observed in gherkin genotypes is in accordance with the results obtained by Munshi et al. (2008). Among the 31 genotypes of Cucumis anguria var. hardwickii collected from Dehradun, Mussourie, Rishikesh and Kotwar in Uttaranchal, Mt. Abu in Rajasathan, Melghat, Khandla ghat, Raigadh Fort, Raigadh, and Ratnagiri in Maharashtra, Panhala and Jeypore in Orissa, Solan and Sirmur in Himachal Pradesh locations in India. The lowest mean per cent disease intensity (PDI) was recorded in IC-277048 $(6.33 \%)$ while the highest PDI was observed in IC$331631(75.33 \%)$ and all the four cultivated varieties (DC-1, DC-2, CHC-1 and CHC-2) showed very high $\mathrm{PDI}$ and susceptible disease reaction. Based on mean PDI, 8 genotypes were categorized as resistant, 13 as moderately resistant, nine as moderately susceptible and one as susceptible.

Among 43 genotypes screened for CMV resistance in gherkin (Cucumis anguria L.) , one genotype showed immune (I) reaction, 15 genotypes showed resistant $(R)$ reaction, 15 genotypes showed moderately resistant (MR) reaction and
11 genotypes showed moderately susceptible (MS) reaction and one showed susceptible (S) reaction. The highest per cent disease incidence was observed in Acc. $48(100 \%)$ and least was in Hyb. 11 (0.00\%) genotype (Kavyashri, 2014). Ekbc et al. (2010) screened more than 350 melon accessions for CMV collected from different ecological parts of Turkey. Out of them, 67 melon accessions, sampled from this germplasm were tested for resistance; no resistant genotype was found to CMV. However, in Forty-five pepper breeding lines inoculated with CMV showed resistant in four lines as reported by Sun XiuDong et al. (2008).

The authors evaluated the F3 progenies to identify the source of resistance through mechanical inoculation and vector transmission. CMV sap was extracted from infected leaves showing characteristics CMV symptoms and confirmed through DAS -ELISA for its reactivity for CMV specific antisera. After confirmation with DAS-ELISA, the inoculum source of CMV was maintained on the gherkin plant and used the same plant as source of inoculum. The repeated experiments were conducted to define resistance. Similarly, vector transmission of CMV was done through aphid (Aphis gossypii Glover) with one hour starvation followed by 10 min AAP and IAP. The response of F3 progenies for level of resistance was found similar both in mechanical and vector transmission. This confirm the reaction of $\mathrm{F} 3$ progenies for $\mathrm{CMV}$ resistance, seven of 179 F3 progenies were found Immune (17, 35 and $62 \mathrm{~F}_{3}$ families derived from cross Acc.1-50, 26 and $34 F_{3}$ family derived from cross Acc.3-50 and 11 and $47 F_{3}$ family from Acc.48-50), however, 17 F3 progenies showed resistant reaction $(\mathrm{R})$.

\section{Conclusion}

Among 179 F3 progenies of gherkin (Cucumis anguria L.) screened for CMV in glasshouse condition, 7 F3 progenies were Immune, 17 Resistant, 76 Moderately Resistant, 73 Moderately Susceptible and 6 were Susceptible to CMV disease infection reaction. These Immune and Resistant F3 genotypes can be further used for the identification of molecular markers in breeding programme.

\section{REFERENCES}

1. Bos, L. (1982). Crop losses caused by viruses. Crop Prot., 1: 263-282. https://www.sciencedirect.com/ science/article/pii/0261219482900023

2. Chandankar, V. D., Mondhe, M. K., Bhoyar, P. R., Ninawe, B. N. and Jadesha, G. (2013). Biophysical characterization, host range and transmission studies of cucumber mosaic virus. Bioscan, 8(2): 437-441. http://www.thebioscan.in/Journals_PDF/8215\% 20V.\%20D.\%20CHANDANKAR.p $\overline{d f}$

3. Coudriet, D. L., 1962, Efficiency of various insects as vectors of Cucumber mosaic and Watermelon mosaic viruses in Cantaloups. J. Econ. Entomo., 55(4): 519- 
520.

4. Ekbc, E., Fidan, H., Yildiz, M. and Abak, K., 2010, Screening of Turkish melon accessions for resistance to ZYMV, WMV and CMV. Not. Sci. Biol., 2:1. https://www.notulaebiologicae.ro/index.php/nsb/ article/view/3555

5. Gracia, O., 2000, First report of ZYMV in Argentina. Plant Dis., 84: 371. https://apsjournals.apsnet.org/ doi/abs/10.1094/PDIS.2000.84.3.371B

6. Havey, M. J., 1996, CMV resistance in three sources of cucumber. Cucurbit Genet. Coop., 19: 32-33. https://www.ars.usda.gov/ARSUserFiles/60800500/ CGC/CGC\%2019\%20(1996).pdf\#page $=42$

7. Kavyashri, V.V., 2014, Survey, biological and molecular characterization and management of cucumber mosaic virus in gherkin (Cucumis anguria L.). M.Sc. (Agri.) Thesis, Univ. Agri. Sci. Bangalore. http:// krishikosh.egranth.ac.in/handle/1/82019

8. Krishna Reddy, M., Devaraj, Raman, R., Jalali, S. and Samuel, D. K., 2003, Outbreak of Tobacco streak virus causing necrosis of cucumber (Cucumis sativus) and gherkin (Cucumis anguria) in India. Plant Dis. 87(10): $1264 . \quad$ https:// apsjournals.apsnet.org/doi/abs/10.1094/ PDIS.2003.87.10.1264B

9. Mandal, B., Pappu, H. R. and Culbreath, A. K., 2001, Factors affecting mechanical transmission of tomato spotted virus to peanut (Arachis hypogae). Plant Dis., 85: 1259-1263. https://apsjournals.apsnet.org/doi/ abs/10.1094/PDIS.2001.85.12.1259

10.Mugadur, N. S. and Nittur, D. S., 2011, Gherkin cultivation in Haveri district of Karnataka: An economic analysis. Contemporary Res. India, 1(3): 42-50.
11.Munshi, A. D., Panda, B. and Mandal, B., 2008, Genetics of resistance to cucumber mosaic virus in $\mathrm{Cu}$ cumis sativus var. hardwickii. Euphytica 164: 501507. https://link.springer.com/article/10.1007/s10681 008-9741-2

12.Nath, P., 1979, Vegetables for the tropical regions, I.C.A.R. Low priced book series No.2, ICAR, New Delhi. 109pp.

13.Ribicki, E. P., 1995, Family Bromoviridae. In: MURPHY, F. A., FAUQUET, C. M., BISHOP, D. H. L., GHABRIAL, S. A., JARVIS, A. W., MARTELLI, G. P., MAYO, M. A., SUMMERS, M. D., Virus Taxonomy, Sixth Report of the International Committee on Taxonomy of Viruses. Springer Verlag, Wien, pp. 450 457

14.Silbernagel, M. J. and Jafari, A. M., 1974, Temperature effects on curly top resistance in Phaseolus vulgaris. Phytopathol., 64: 825-827. http:// www.sidalc.net/cgi-bin/wxis.exe/?

IsisScript $=$ catalco xisandmethod $=$ postandformato $=2 a$ ndcantidad $=1$ andexpresion $=m f n=054399$.

15.Sukumaran, A., 2007, Gherkin exports may slow on lower demand from Russia. Live Mint Wallstreet $J$.

16.Sun Xiudong, Lei, J. and Zhou, S., 2008, Identification of CMV and screening for CMV resistance of pepper in Guangzhou. China vegetables, 6(3): 11-14.

17.Varma, A. and Giri, B. K., 1998, Virus diseases. In: Nayar NM, More TA Cucurbits. Oxford and IBH Publishing Co. Pvt. Ltd, New Delhi, 225-245.

18.Viraktamath, C. A., Malik, B., Chandrashekar, S. C., Ramakrishna, B. V. and Praveen, H. M., 2003, Information on insect pests and diseases of gherkin and their management. Univ. Agri. Sci., Bangalore, 33pp. 